\title{
Effect of Addition of Composite Filler Volume on Ganoderma Boninense Mushroom Against Tensile Strength, Modulus of Elasticity, and Filler Distribution
}

\author{
Muhammad Rafiq Yanhar, Ahmad Bakhori Nasution, Siti Rahmah Sibuea, Abdul Haris Nasution \\ Faculty of Engineering, Universitas Islam Sumatera Utara, Medan, Indonesia \\ *Corresponding author E-mail: rafiq@ft.uisu.ac.id
}

\begin{abstract}
This study aims to determine the effect of increasing filler volume of ganoderma boninense mushroom on tensile strength, modulus of elasticity, and distribution of the reinforcing particles. The composite reinforcement particle volume varies from 5\%, 10\%, $15 \%$, and $20 \%$. The mushroom is soaked with $\mathrm{NaOH}$ solution for 1 hour to remove dirt and sap that can reduce the bonds between matrix and particles. After that the mushrooms are made into mesh 50 -sized particles using a blender with a rotation of $28,000 \mathrm{rpm}$. From the test results it can be seen that the highest tensile strength of $23.21 \mathrm{MPa}$ is in the composite with a filler volume of $5 \%$. The addition of particle volume to $10 \%$ makes the tensile strength slightly decrease to $21.04 \mathrm{MPa}$. The addition of filler volume to $15 \%$ and $20 \%$ causes the tensile strength to decrease to $20.55 \mathrm{MPa}$ and $19.68 \mathrm{MPa}$. From the test results it can be seen that the lowest modulus of elasticity is in the composite with a filler volume of $5 \%$. The addition of particle volume to $10 \%$ makes the modulus of elasticity rise to $83.15 \mathrm{MPa}$. The addition of filler volume to $15 \%$ and $20 \%$ causes the modulus of elasticity to increase to $126.77 \mathrm{MPa}$ and $159.10 \mathrm{MPa}$. This shows that the more presence of ganoderma fungi in the composite causes the composite to become more elastic, thereby increasing the modulus of elasticity and decreasing tensile strength. The results of SEM photos showed the spread of mushroom powder at a volume of 5\%, $10 \%$, and $15 \%$ less evenly distributed, while in the filler $20 \%$ saw the spread of powder quite evenly.
\end{abstract}

Keywords: Ganoderma boninense mushroom, Tensile strength, Modulus of elasticity, Particle distribution

\section{Introduction}

In 2017, production of Indonesian crude palm oil (CPO) is 37.8 million tons with an area of oil palm plantations reaching 14.03 million hectares. In terms of state revenue, exports generated from palm oil products in 2017 reached 21.25 billion US dollars or around Rp. 287 trillion. The area of oil palm plantations in Indonesia is expected to continue to grow to 20 million hectares by 2020 , and it is estimated that Indonesia can produce at least 40 million tons of palm oil per year starting in 2020 .

But the growth of palm oil is often constrained due to ineffective management and other problems that can affect palm oil production. One of the obstacles to oil palm plantations is stem rot caused by Ganoderma boninense. G. boninense is known not only to attack oil palm plants at the production stage but can also attack during the nursery stage. Typical symptoms before the formation of the mushroom fruit body, marked by decay at the base of the stem, causing dry rot in the deep tissue.

Oil palm plantations on peatlands are even more susceptible to ganoderma boninense attacks because the oil palm stumps that are left in the soil are the strongest source of infection in the rejuvenation garden (former oil palm).

The results showed that the more often oil palm plantations experienced rejuvenation or in the oil palm plantation area previously planted with coffee, rubber or other crops, would cause a high incidence of BPB disease. BPB disease can cause direct loss of yield to palm oil and a decrease in the weight of fresh fruit bunch- es. Damage caused can reach $80 \%$ to $100 \%$, it can even cause death in attacked plants.

In this study, ganoderma boninense mushroom will be used as a composite filler to determine the tensile strength, modulus of elasticity, and the spread of the filler.

Other studies that use natural fibers as composite materials include: teki grass [1], banana peel [2], wood [3] - [5], leaf Pandan Alas [6] pineapple leaves [7], bamboo fiber [8], [9] and rice husk [10] showed significant influence on composite generated.

\section{Research Method}

Tensile test specimens are made with ASTM D 638-02a type I standard. This type is chosen because it has a middle width of 13 $\mathrm{mm}$, so it is not easily broken when removed from the mold. Unlike type IV which only has a middle width of $6 \mathrm{~mm}$, so many specimens are broken or cracked when removed from the mold (Rafiq, 2017). The matrix used in this research is BQTN 157 EX Polyester Resin, while the filler is taken from ganoderma boninense mushroom powder, which is a fungus that can damage and even kill the oil palm trees. The method for making composite specimens can be seen below:

a. Ganoderma boninense mushroom is washed thoroughly with water, then soaked in $5 \% \mathrm{NaOH}$ solution for 1 hour to remove sap and dirt that can reduce the bond between matrix and filler. 


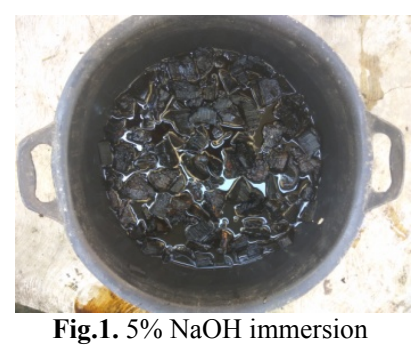

b. After that the mushrooms are dried by putting them in the oven for 12 hours to remove the water content.

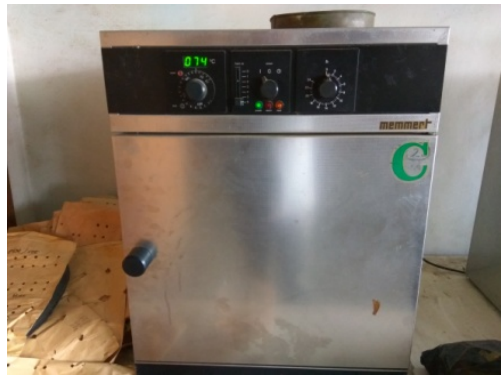

Fig. 2. Oven

c. After the mushroom is dried, then it is made into particles with a blender of $28,000 \mathrm{rpm}$, sifted with a mesh 50 , and the volume is measured according to the desired for use in making the specimen. While the matrix that acts as an adhesive is BQTN 157 EX polyester resin. This composite is made using volume variations from the particles and matrix. Volume comparisons can be seen as follows:

1) Filler (mushroom particles) $5 \%$ and $95 \%$ matrix.

2) Filler $10 \%$ and $90 \%$ matrix.

3) Filler (mushroom particles) $15 \%$ and matrix $85 \%$.

4) Filler $20 \%$ and $80 \%$ matrix.

d. Molds made of metal are smeared with wax so that after hardening the specimen will be easily removed from the mold. While the bottom of the mold is coated with waxed wax.

e. Filler and polyester BQTN 157 EX Resin which has been mixed with a hardener with a ratio of 100: 1, stirred evenly and then poured into the mold.

f. After the resin and filler mixture begins to thick, the glass is placed on the top of the mold and pressed with a ballast to remove trapped void (air bubbles) as well as to level the specimen surface.

g. Let the specimen harden for 12 hours, after which the mold is opened and the specimen has formed

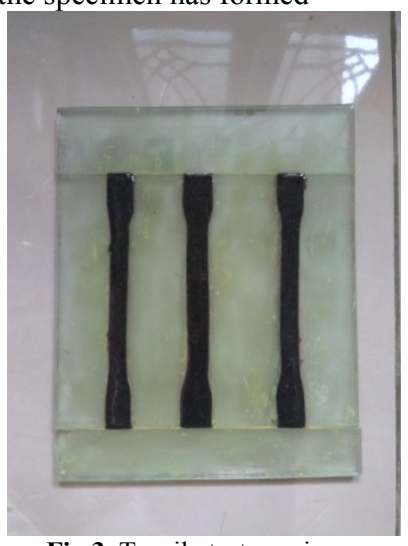

Fig.3. Tensile test specimen

h. In this study tensile testing was carried out with the machine servopulser in the laboratory of the USU Mechanical Engineering Department, with a pull force of $5000 \mathrm{~kg}$ and a speed of $1 \mathrm{~mm} / \mathrm{min}$

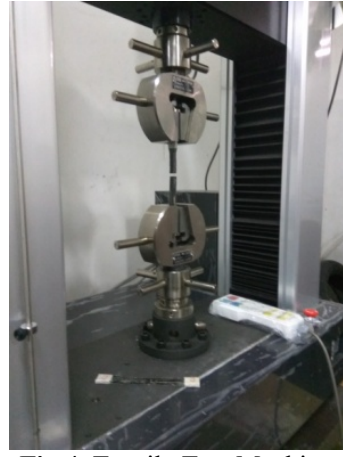

Fig.4. Tensile Test Machine

\section{Result and Discussion}

Tensile test results can be seen as follows:

\begin{tabular}{|c|c|c|c|}
\hline $\begin{array}{l}\text { Composite Volume Parti- } \\
\text { cle }(\%)\end{array}$ & $\begin{array}{l}\text { Specimen } \\
\text { (n) }\end{array}$ & $\begin{array}{l}\text { Tensile } \\
\text { Strength } \\
(\mathrm{MPa})\end{array}$ & $\begin{array}{l}\text { Average } \\
\text { Tensile } \\
\text { Strength } \\
(\mathrm{MPa}) \\
\end{array}$ \\
\hline 5 & $\begin{array}{l}\text { Specimen } \\
1 \\
\text { Specimen } \\
2 \\
\text { Specimen } \\
3\end{array}$ & $\begin{array}{l}22.43 \\
23.99 \\
23.27\end{array}$ & 23.21 \\
\hline 10 & $\begin{array}{l}\text { Specimen } \\
1 \\
\text { Specimen } \\
2 \\
\text { Specimen } \\
3\end{array}$ & $\begin{array}{l}22.99 \\
18.8 \\
21.34\end{array}$ & 21.04 \\
\hline 15 & $\begin{array}{l}\text { Specimen } \\
1 \\
\text { Specimen } \\
2 \\
\text { Specimen } \\
3\end{array}$ & $\begin{array}{l}19.8 \\
21.38 \\
20.47\end{array}$ & 20.55 \\
\hline 20 & $\begin{array}{l}\text { Specimen } \\
1 \\
\text { Specimen } \\
2 \\
\text { Specimen } \\
3\end{array}$ & $\begin{array}{l}18.67 \\
20.15 \\
20.22\end{array}$ & 19.68 \\
\hline
\end{tabular}

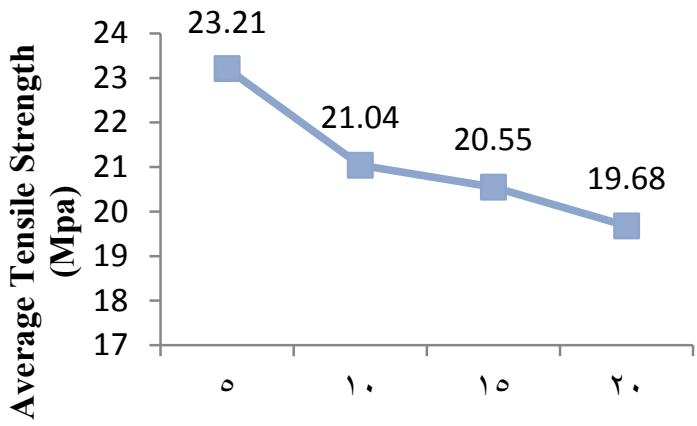

Composite Volume Particle (\%)

Fig.5. Tensile strenght graphic

From the test results it can be seen that the highest tensile strength of $23.21 \mathrm{MPa}$ is in the composite with a filler volume of 5\%. The addition of particle volume to $10 \%$ makes the tensile strength slightly decrease to $21.04 \mathrm{MPa}$. The addition of filler volume to $15 \%$ and $20 \%$ causes the tensile strength to decrease to $20.55 \mathrm{MPa}$ and $19.68 \mathrm{MPa}$.

This shows the increasing presence of ganoderma fungi in the composite causes an improvement in the stiffness properties of the 
composite, thereby reducing its tensile strength. When observed the percentage decrease in composite tensile strength from the filler volume is relatively small. From the filler $5 \%(23.21 \mathrm{MPa})$ to $10 \%(21.04 \mathrm{MPa})$ the decrease in tensile strength was $10.31 \%$. From $10 \%(21.04 \mathrm{MPa})$ to $15 \%(20.55 \mathrm{MPa})$ is $2.38 \%$. And from $15 \%(20.55 \mathrm{MPa})$ to $20 \%(19.68 \mathrm{MPa})$ is $4.42 \%$. But if we observe the filler volume from $5 \%-20 \%$ then the tensile strength is down from $23.21 \mathrm{MPa}$ to $19.68 \mathrm{MPa}$ or $17.93 \%$, then this number is quite significant. And interesting to be investigated further, how much the decrease in tensile strength if the filler volume continues to increase, for example up to $50 \%$.

Table 2. Elasticity Modulus

\begin{tabular}{|c|c|c|c|}
\hline $\begin{array}{l}\text { Composite Volume } \\
\text { Particle }(\%)\end{array}$ & $\begin{array}{l}\text { Specimen } \\
\text { (n) }\end{array}$ & $\begin{array}{l}\text { Elasticity } \\
\text { Modulus } \\
(\mathrm{MPa})\end{array}$ & $\begin{array}{l}\text { Average Elastici- } \\
\text { ty Modulus } \\
(\mathrm{MPa})\end{array}$ \\
\hline 5 & $\begin{array}{l}\text { Specimen } 1 \\
\text { Specimen } 2 \\
\text { Specimen } 3\end{array}$ & $\begin{array}{l}27.98 \\
21.77 \\
25.46 \\
\end{array}$ & 25.07 \\
\hline 10 & $\begin{array}{l}\text { Specimen } 1 \\
\text { Specimen } 2 \\
\text { Specimen } 3\end{array}$ & $\begin{array}{l}72.86 \\
92.07 \\
84.52 \\
\end{array}$ & 83.15 \\
\hline 15 & $\begin{array}{l}\text { Specimen } 1 \\
\text { Specimen } 2 \\
\text { Specimen } 3\end{array}$ & $\begin{array}{l}132.28 \\
125.94 \\
122.11\end{array}$ & 126.77 \\
\hline 20 & $\begin{array}{l}\text { Specimen } 1 \\
\text { Specimen } 2 \\
\text { Specimen } 3\end{array}$ & $\begin{array}{l}158.53 \\
157.82 \\
160.96\end{array}$ & 159.10 \\
\hline
\end{tabular}

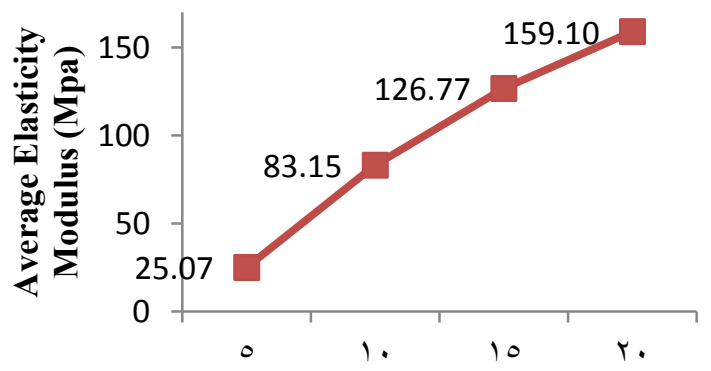

Composite Volume Particle (\%)

Fig.6. Modulus elasticity graphic

From the test results it can be seen that the lowest modulus of elasticity is in the composite with a filler volume of $5 \%$. The addition of particle volume to $10 \%$ makes the modulus of elasticity rise to $83.15 \mathrm{MPa}$. The addition of filler volume to $15 \%$ and $20 \%$ causes the modulus of elasticity to increase to $126.77 \mathrm{MPa}$ and 159.10 MPa. This shows that the more presence of ganoderma fungi in the composite causes the composite to become more elastic, thus increasing the modulus of elasticity.

When considered the percentage increase in composite elastic modulus from the filler volume is quite large. From the 5\% filler $(25.07 \mathrm{MPa})$ to $10 \%(83.15 \mathrm{MPa})$ the increase in the modulus of elasticity was $231.7 \%$. From filler $10 \%(83.15 \mathrm{MPa})$ to $15 \%$ $(126.77 \mathrm{MPa})$ was $52.45 \%$. And $15 \%(126.77 \mathrm{MPa})$ to $20 \%$ $(159.10 \mathrm{MPa})$ is $25.5 \%$. But if we look at the percentage increase in modulus of elasticity, the filler volume from $5 \%-20 \%, 25.07$ $\mathrm{MPa}$ to $159.01 \mathrm{MPa}$ is $535.5 \%$, then this figure is very large. And interesting to be investigated further, how much the decrease in tensile strength if the filler volume continues to increase, for example up to $50 \%$.

The results of the SEM (Scanning Electron Microscope) photo show the spread of mushroom powder. $5 \%$ filler photo looks too much powder. In the $10 \%$ filler it can be seen that the spread of powder is uneven and there are air bubbles. In the filler $15 \%$, the powder is slightly gathered and the distribution is not evenly distributed. In $20 \%$ filler, the powder spread is quite even.

This is because polyester resin itself is quite thick and thicker after being mixed with $1 \%$ hardener, so that it can cause fillers not to spread well and accumulate at a point, even though it has been stirred evenly.

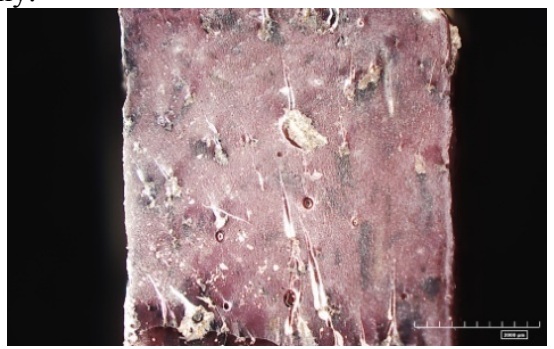

Fig.7. SEM photo of 5\% filler

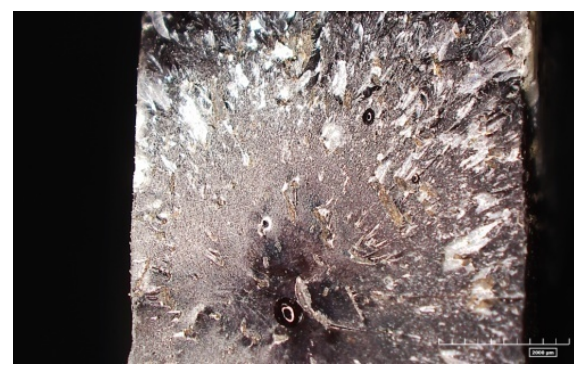

Fig. 8. SEM photo of $10 \%$ filler

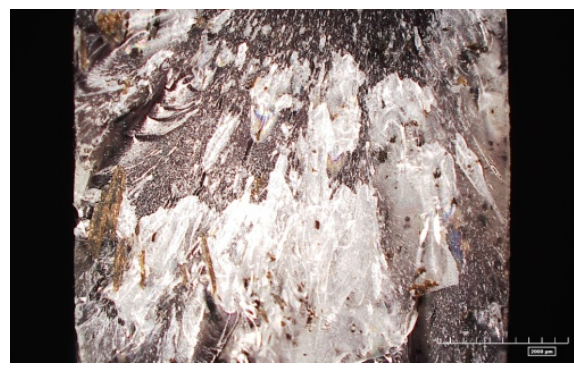

Fig.9. SEM photo of $15 \%$ filler

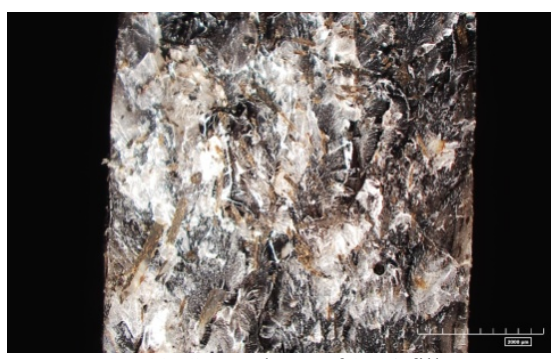

Fig. 10. SEM photo of $20 \%$ filler

\section{Conclusion}

The highest tensile strength of $23.21 \mathrm{MPa}$ is in the composite with a filler volume of $5 \%$. The addition of particle volume to $10 \%$ makes the tensile strength slightly decrease to $21.04 \mathrm{MPa}$. The addition of filler volume to $15 \%$ and $20 \%$ causes the tensile strength to decrease to $20.55 \mathrm{MPa}$ and $19.68 \mathrm{MPa}$.

The lowest modulus of elasticity is in the composite with a filler volume of $5 \%$. The addition of particle volume to $10 \%$ makes the modulus of elasticity rise to $83.15 \mathrm{MPa}$. The addition of filler volume to $15 \%$ and $20 \%$ causes the modulus of elasticity to increase to $126.77 \mathrm{MPa}$ and $159.10 \mathrm{MPa}$.

This shows the increasing presence of ganoderma fungi in the composite causing the composite to become more elastic, thus increasing the modulus of elasticity and decreasing tensile strength The results of SEM photos showed the spread of mushroom powder at a volume of $5 \%, 10 \%$, and $15 \%$ less evenly distributed, while in the filler $20 \%$ saw the spread of powder quite evenly. 


\section{Acknowledgements}

The authors wish to acknowledge the Direktorat Riset dan Pengabdian Masyarakat, Direktorat Jendral Penguatan Riset dan Pengembangan Kementerian Riset, Teknologi, dan Pendidikan Tinggi.

\section{References}

[1] Yanhar, M. Rafiq M. R. Harahap, A. Bachori, S. Napid, and I. S. Poneni, "Fiber Laminate Adding Effect to Tensile Strength, Hardness , and Fault Surface of Teki Grass ( Cyperus Rotundus ) Composite," vol. 7, pp. 394-397, 2018.

[2] M. O. C. Pereira, Paulo H, F. Benini, Kelly C, C. Watashi, Cintia Y Voorwald, Herman J, H. Cioffi, "Characterization of High Density Polyethylene (HDPE) Reinforced with Banana Peel Fibers," Bioresour, vol. 8, no. 2, pp. 2351-2365, 2013.

[3] L. A. G. M. W. Gallagher, "The Effect of Micron Sized Wood Fibers in Wood Plastic Composites," J. Mod. Technol., vol. 15, no. 3, pp. 357-374, 2012.

[4] A. C. Atuanya, C, U. Ibhadode, A, O, A, Igboanugo, "Potential of Using Recycled LDPE in Wood Composites Board," African J. Environ. Sci. Technol., vol. 5, no. 5, pp. 389-396, 2011.

[5] A. V. Ndlovu, S, S. Reenen, A, JS. Luyt, "LDPE-Wood Composites Untilizing Degradable LDPE as Compatibilizer," Elsevier J. Compos. Part A, vol. 51, pp. 80-88, 2013.

[6] L. A. J. Nourbakhsh, A. Kokta, B. V Ashori, Alireza, "Effect of a Novel Coupling Agent, Polybutadiene Isocyanate, on Mechanical Properties of Wood-Fiber Polypropylene Composites," SAGE J. Reinf. Plast. Compos., vol. 27, no. 16-17, 2008.

[7] M. C. Taufik and Astuti, "Sintesis dan Karakterisasi Sifat Mekanik serta Struktur Mikro Komposit Resin yang Diperkuat Serat Daun Pandan Alas (Pandanus dubius)," J. Fis. Univ. Andalas, vol. 3, no. $1,2014$.

[8] S. Sreenivasulu and A. C. Reddy, "Mechanical Properties Evalution of Bamboo Fiber Reinforced Composite Materials," Int. J. Eng. Res., no. 3, 2014.

[9] P. . Nwanonenyi, S, CAnyanwu, "Studies on the Properties of Peneapple Leaves Powder Filler Low Density Polyethylene," J. SAVAP Int. Nat. Sci. Apllien Phys., vol. 4, no. 1, pp. 359-367, 2013.

[10] Fathanah, "Kualitas Papan Komposit dari Sekam Padi dan Plastik HDPE Daur Ulang Menggunakan Maleic Anhydride (MAH) sebagai Compatibilizer," J. Rekayasa Kim. dan Lingkung., vol. 8, no. 2, pp. 53-59, 2011.

[11] Yanhar, M. Rafiq and A. Haris Nasution, "Mass variation effect of teki grass (cyperus rotundus) composite against tensile strength and density,” IOP Conf. Ser. Mater. Sci. Eng., vol. 352, no. 1, 2018 